\title{
4000 Jaar van soeke na God
}

\author{
Frances Klopper \\ Departement Ou Testament en Ou Nabye Oosterse Studie \\ Universiteit van Suid Afrika
}

\begin{abstract}
The 4000-year quest for God

South Africans live in a time of growing unease amongst Afrikaansspeaking Christians about the traditional God-image of their childhood. As a con-sequence, churches are losing members - which is of concern to the church's leaders. By referring to Karen Armstrong's book, A History of God (1999), this article shows that rethinking the idea of God is not new and that healthy iconoclasm is part and parcel of religions as evolving and changing organisms. Over the past 4000 years, each generation created an image of God that worked for them. The article reflects on the God of Judaism, the Christian God, the God of Islam, the God of the philosophers, the mystics, the reformers and the thinkers of the Enlightenment to the eventual eclipse of God in twentieth-century Europe. The purpose of the exercise is to encourage Christians to engage with the process and create a sense of God for themselves by taking heed of the negative and positive moments in God's long history.
\end{abstract}

\section{INLEIDING EN MOTIVERING}

God begin toenemend ongeloofwaardig raak vir Afrikaanssprekende Christene van die Gereformeerde tradisie. Die beeld van God waarmee hulle grootgeword het, bevredig nie meer nie omdat dit nie sin maak in die veranderde tye waarin hulle leef nie. Ou waardes word bevraagteken en die Christelike tradisie word oorboord gegooi, sodat kerke lidmate verloor en naarstiglik redes vir die probleem moet identifiseer om oplossings te vind (vgl Müller 2004b:12). Maar kritiese vraagstelling oor God, godsdiens en die kerk is nie nuut nie. In Wes-Europa is God met die oorgang na die negentiende eeu reeds dood verklaar en het die einde van die kerklike tradisie in die vorige eeu aangebreek. Dit blyk dat die kritiese denke van die agtiende-eeuse Verligting ons in Suid Afrika verbygegaan het en daarom is kerkleiers en gelowiges van vandag nie toegerus om die situasie wat as 'n krisis beleef word, te hanteer nie. Aan die ander kant herinner Krüger (1995:59) ons dat religieë nie statiese, homogene entiteite is nie. Hulle is multiforme, lewende, veranderende organismes, elkeen opgeneem in groot historiese prosesse. Nuwe religieë word as mutasies uit hulle voorgangers gebore - soos die 
Christendom uit Judaïsme ontstaan het - of hulle raak irrelevant en sterf om plek te maak vir ander simbole wat sin gee aan die wonder en pyn van die lewe. Sonder om 'n voorspelling te waag oor die toekoms van die Christendom, lyk dit onafwendbaar dat ons 'n nuwe bedeling met nuwe denke oor God in Suid Afrika binnegaan.

Die geskiedenis van God is so oud soos die mensdom self. Homo sapiens was spirituele wesens vanaf die oomblik toe die mens as mens herkenbaar geword het. Vondste van 35000 jaar-oue kindergrafte van WesEuropese grotbewoners, wys dat die liggame doelbewus in 'n spesifieke posisie geplaas is, met pigmentasie versier is en dat sekere objekte in die graf geplaas is om voorsiening te maak vir die reis na 'n misterieuse onbekende (vgl Haught 1990:1). Soos kuns, is godsdiens 'n poging om die misterie en tragedie van ons wonderlike en skrikwekkende wêreld uit te druk en daarvan sin te probeer maak. Die idee van God of 'n godheid, het een van die grootste menslike idees van alle tye geword en in alle kulture het dit ' $n$ beslissende rol in die loop van hulle geskiedenis gespeel. Elke periode in die wêreldgeskiedenis moes egter opnuut 'n beeld van God skep wat vir daardie tyd en omstandighede effektief sou wees.

Om die leser in baie woorde bloot te stel aan nog 'n mening oor God, is nie die doel van hierdie skrywe nie. Die diskussies oor God wat tans plaasvind is ter insae op die internet, rubrieke en briewekolomme van die dagblaaie en talle publikasies wat die afgelope tyd verskyn het. ${ }^{1}$ Hierdie artikel is 'n poging om die geskiedenis van die idee van God oor die afgelope 4000 jaar, vanaf $2000 \mathrm{VAJ}^{2}$ tot waar ons vandag is, in konteks te plaas. Volgens Jacobs (2004) lê die waarde van 'n historiese ondersoek daarin "dat dit ons laat besef dat alles wat ons oor God het, deur mense gegaan het en nog steeds gaan; dat geen enkele woord oor God van iewers op 'n klaar-beskrewe bladsy aangewaai gekom het nie." En omdat dit 'n menslike verhaal is, kan ons lesse en waarskuwings daaruit neem om die toekoms mee tegemoet te gaan.

Karen Armstrong se invloedryke boek, A History of God (1999), dien as grondteks vir ons verhaal. Sy bespreek die idee van God soos dit deur die eeue in die drie monoteïstiese religieë, naamlik Judaïsme, die Christendom en Islam, verstaan is.

\footnotetext{
${ }^{1}$ Spangenberg (2004:274-293) se oorsig oor die debat oor God wat sedert 1998 onder Afrikaanssprekende Christene in verskillende publikasies plaasgevind het, is ' $n$ handige verwysingsbron.

${ }^{2}$ Die geskiedenis van die idee van God word vanuit die Joodse, Christelike en Moslemse perspektief bekyk, so die afkortings VAJ (Voor die Algemene Jaartelling) en AJ (Algemene Jaartelling) word gebruik.
} 


\section{IN DIE BEGIN}

Ons verhaal begin by die antieke wêreld van die ou Nabye Ooste tussen die Tigris en die Eufraat toe mense nog gelewe het asof hulle deur kosmiese magte, of gode, omring was. Die natuur was die arena waar wispelturige gode in interaksie met mekaar die gesteldheid van die wêreld bepaal het. Die mens kon deur mites en rituele deel word van die drama daarbuite en die gode teen mekaar afspeel of laat saamwerk om in hulle basiese behoeftes van vrugbaarheid en goeie oeste, te voorsien (Frymer-Kensky 1992:86; Eliade 1959:125-126). In 'n Ugaritiese mite word die siklus van die seisoene toegeskryf aan 'n stryd tot die dood tussen Baäl (die god van vrugbaarheid en winterreën) en Mot (die god van onvrugbaarheid en die somerseisoen). Baäl moes in die somer sterf sodat die graanoes kon ryp word, en met die vroeë herfsreën keer hy terug sodat die landerye vir die volgende seisoen voorberei kon word. Deur die rituele opvoering van die mite, besweer die gemeenskap die werklikheid van droogtes en hongersnood waaroor hulle andersins geen beheer gehad het nie ( $\mathrm{vgl}$ Gibson 1978:14-19). Die dood van 'n god en 'n triomfantelike terugkeer sou ook in die godsdiens van die een God van die Jode, Christene en Moslems opduik. Rituele in nabootsing van 'n god is steeds 'n belangrike religieuse handeling: deur te rus op die sabbat of die nagmaalbrood te breek, is vir Christene betekenisvol omdat dit in die verlede deur hulle God uitgevoer is (Armstrong 1999:12).

Ou Israel was onlosmaaklik deel van die ou Nabye Ooste en het die ou Nabye-Oosterse spiritualiteit gedeel. Die vroeë god van die Hebreeuse Bybel kan nie met een naam of eienskap beskryf word nie. Sy ${ }^{3}$ herkoms is teenstrydig en sy biograwe is ook nie geïnteresseerd in die besonderhede waarin ons geïnteresseerd is nie. Daarvoor was Israel se godsdiens te prakties en was van Jahwe hoofsaaklik verwag om effektief te wees in hulle daaglikse bestaan. Sy biografie is deurspek met mitologiese elemente en afgesien van aanduidings dat hy ' $n$ wederhelfte gehad het, was hy nie die enigste god nie, maar lid van die groter ou Nabye-Oosterse gode-panteon. In die voorouerverhale leer ons hom ken as 'n betrokke god wat gemoeid is met die alledaagse nood en behoeftes van die families. Hy gee advies oor die keuse van hulle toekomstige vroue, lei hulle in hulle omswerwinge en praat met hulle in hulle drome. Maar hy is ook wispelturig. Hy verskyn aan Abraham by Mamre en belowe aan hom 'n seun, maar eis dan dat hierdie langverwagte seun op 'n brandstapel geoffer word. In die Eksodusmite verskyn hy as 'n genadelose en partydige God wat ter wille van sy volk, slegs die Egiptenare se eersgeborenes laat omkom. Later sien ons

\footnotetext{
${ }^{3} \mathrm{Na}$ God word deurgaans as "hy" verwys omdat die idees van mense wat God as manlik beskou het, onder die loep kom.
} 


\section{Jaar van soeke na God}

hom as 'n bloeddorstige oorlogsgod wat vrou, kind en dier deur die ban laat uitwis. Voorbeelde kan vermenigvuldig word, maar in die verhaal van Elia en die profete van Baäl vind ons die laaste mitologiese verslag oor die verlede en die eerste spore van 'n beweging na een God (vgl Armstrong 1999:36).

Hierdie beweging staan in die teken van veranderende tye, bekend as die Aksiale periode, wat van 800 tot 200 VAJ oor die hele ou beskaafde wêreld, van China tot Egipte, plaasgevind het (Gnuse 1997:210-214). Nuwe voorspoed het ontwikkel met die ontstaan van 'n handelaarsklas wat die mag van die tempel en die paleis na die markplek verskuif het. Nuwe godsdienssisteme soos Taoisme, Boeddhisme, Hinduisme en monoteïsme wat in diè tyd ontwikkel het, maak erns met die uitbuiting en ongelykheid wat 'n markekonomie meebring. Monoteïsme het altyd in stede ontstaan waar intellektuele gesprek plaasgevind het oor kwessies soos sosiale ongeregtigheid, menslike lyding en God se rol daarin (vgl Baly 1970:253-278). Ons sal dit weer teëkom met die ontstaan van Islam in $600 \mathrm{AJ}$. In die bybelse verhaal oor God, was die Hebreeuse profete sterk verteenwoordigers van die monoteïserende stemme.

\section{DIE EEN GOD VAN DIE JODE}

By die profete van die Hebreeuse Bybel bemerk ons die gesindheid van die Aksiale godsdienste. In 'n visioen van Jesaja van Jerusalem in 742 VAJ, is God 'n simbool van transendente verhewenheid. Hy is in beheer van die geskiedenis van al die volke (Jes 6:1-3). Hy wil nie meer gedien word deur die ou kultiese rituele wat die mens terugplaas in mitiese tyd nie en hy word gewalg deur die kultiese feeste en die offerdiens in die tempel. In die sosialistiese gees van die godsdienste van die tyd, moes die Israeliete die innerlike betekenis van hulle godsdiens uitleef deur in hulle daaglikse lewe medemenslikheid te bewys (Jes 1:13-17). In 752 VAJ hoor ons Amos van die Noordryk se kritiek op die sosiale ongeregtigheid van sy tyd. Hosea verklaar in dieselfde tyd afgodediens as die nuwe sonde. Die bespotting van die afgodsbeelde van hulle bure was die begin van diep onverdraagsaamheid teenoor ander godsdienste - 'n nuwe houding wat 'n kenmerk sou word van veral die Christelike en Islamse monoteïsme (Armstrong 1999:61-62). Volgens die Deuteronomistiese hervormers van 600-500 VAJ, was God 'n jaloerse God wat sy uitverkore volk met 'n voorwaardelike verbond aan hom gebind het. Gedurende die Babiloniese ballingskap (587-538 VAJ) is dit Deuterojesaja, skrywer(s) van Jesaja 40-55, wat Jahwe as die enigste God verklaar wat altyd buite die bereik van menslike konsepte sou bly (Jes 45:5-6) (Gnuse 1997:207). Dit het die legendariese figuur Job ook later geleer: 
kritiese vrae oor God is goed, maar kan nie met die intellek alleen beantwoord word nie (vgl Armstrong 1999:80).

Monoteïstiese Judaïsme is dus in ballingskap is gebore, nie omdat die een God rasioneel aanvaar is nie, maar omdat hy effektief was deur hoop en inspirasie aan die ballinge in hulle hopelose omstandighede te bied. Nà die ballingskap het die profete stil geword en sou daar nie meer direkte kontak met God plaasvind nie. Die priesterskrywers wat die Pentateug in dié tyd geherinterpreteer het, druk Jahwe se teenwoordigheid in terme van sy "heerlikheid" (kavod) uit (Eks 40:34-35). Hy is nie 'n persoonlike god nie, maar 'n krag van heiligheid in die profane wêreld. In die woestyn is hy teenwoordig in die tent van samekoms en in Jerusalem in die allerheiligste van die tempel (Geller 1997:278-279).

Die Jode se godsbeskouing moes weer hersien word na Augustus van $70 \mathrm{AJ}$, toe Titus Jerusalem en die tempel vernietig het en hulle weer eens in ballingskap moes gaan. Hulle behoefte was aan 'n god wat nà die verlies van die tempel in hulle midde teenwoordig sou wees waar hulle ookal in diaspora verkeer. Die rabbi's ontwikkel 'n godsbeskouing waarvolgens elke gesin en familie God kon nader sonder bemiddeling van rituele of priesters as tussengangers. Die shekinah word 'n gewilde sinoniem vir God om sy beskermende teenwoordigheid uit te druk. Hy kon nie in formules omskryf word nie maar moes deur elke mens subjektief ervaar word. Tot vandag word dogmas oor God nie in die Judaïsme voorgeskryf nie omdat dit die misterie van God sal inperk. Die Joodse God was nie meer Jahwe nie, van sy naam het net die onuitspreeklike konsonantiese vorm, JHWH, oorgebly (Geller 2000:318).

Jahwe van Israel, wat met tye onmenslike wreedheid aangestig het, het deur die eeue ontwikkel in 'n god wat die Jode met respek na hulle medemens laat kyk het. Volgens Gnuse (1997:22) se onderskeiding tussen 'n "monoteïsme van bo" wat monolitiese orde en patriargale verdrukking ondersteun, is die Judaïsme se "monoteïsme van onder" 'n godsdiens van onderdruktes wat uit ervaring gegroei het. Rabbi Akiba leer dat God gevind word waar liefdadigheid en welwillendheid teenoor die naaste bewys word (vgl Armstrong 1999:91-94). Hier kom die ideaal van die rabbi's baie na aan die Christendom se gebod van "liefde vir die naaste" wat uit dieselfde tradisie sou groei.

\section{4. 'N VERLOSSER VIR DIE NIE-JODE}

Terwyl die rabbi's in Jerusalem lang redenasies gevoer het, het 'n charismatiese wysheidsleraar en geloofsgeneser in die noorde van Palestina met sy loopbaan begin. Van Jesus weet ons min (vgl vd Heever \& Scheffler 2001:101-119). Die eerste vollengte berig oor sy lewe was die Markus- 


\section{Jaar van soeke na God}

evangelie wat ongeveer veertig jaar na sy dood geskryf is en teen daardie tyd is historiese feite deur mitiese elemente oorskryf wat meer van sy betekenis vir sy volgelinge weergee as wat dit 'n akkurate biografie is. Gedurende sy lewe het 'n groep Jode gedink dat hy die Messias was, maar toe word hy soos 'n gewone misdadiger deur die Romeine gekruisig. Ten spyte van die verleentheid van 'n messias wat so'n dood moes sterf, kon sy volgelinge nie glo dat hulle geloof in hom misplaas was nie. Gerugte dat sy graf na drie dae leeg was en dat sommige hom gesien het, het die rondte gedoen en sy dissipels het geglo dat hy spoedig sou terugkeer om die Messiaanse koninkryk van God in te lui. Sy volgelinge het volgehou om daagliks die tempel te besoek, want Jesus was 'n Jood en die beweging wat hy geïnisieer het, was gefokus op wat dit beteken om 'n toegewyde Jood te wees (Van den Heever \& Scheffler 2001:100). In die lig van wat hierbo gesê is van die rabbi's se etos van "doen aan ander", skets Lukas die Jesus-beweging as 'n groep geesvervulde mense wat die armes versorg en die uitgeworpenes van die gemeenskap, soos vroue, in gemeenskaplike maaltye betrek het (Van den Heever \& Scheffler 2001:129). Na sy dood het Jesus vir sy volgelinge (besluit dat hy) goddelik geword (was), alhoewel die inkarnasie as leerstelling eers in die vierde eeu gefinaliseer sou word.

Die Christelike geloof was aanvanklik nie 'n eenvormige beweging met 'n samehangende teologie nie, maar het bestaan uit diverse gemeenskappe met uiteenlopende ideologieë uit die Judaïsme en die tradisies van die GrieksRomeinse wêreld (vd Heever \& Scheffler 2001:121). In die tweede eeu het die geskrifte van die Apologete (bekeerlinge geskool in die Grieks-Romeinse filosofiese tradisie), begin verskyn om die bestaan van die Christelike geloof te regverdig. Die meeste Apologete spreek 'n onverbloemde aanbidding vir Christus as openbaring van die wese van God uit - gegiet in die taal van die filosofie. Deur insette van teoloë soos Origines, Clemens van Alexandrië en Plotinus sowel as die "afwykende" idees van die Gnostisisme en Marcionisme, is die Christelike belydenis geskaaf om in 'n gesofistikeerde godsdiens te ontwikkel. Daarom het dit aanklank gevind by hoogs intelligente denkers met die vermoë om dit vir die Grieks-Romeinse wêreld aanvaarbaar te maak (vgl Armstrong 1999:125; Noss 1980:440-443).

In die Ooste het die Christendom vinnig gegroei en teen 235 AJ was dit een van die belangrikste godsdienste in die Romeinse Ryk. In 312 AJ word keiser Konstantyn 'n Christen en word dit as die staatsgodsdiens verklaar. Nou ontstaan probleme wat die nuwe kerk in strydlustige kampe verdeel. 


\section{DRIE-EENHEID: DIE GOD VAN DIE CHRISTENDOM}

Rondom 320 AJ ontstaan 'n hewige debat in die kerke van Egipte tot KleinAsië wat begin is deur Arius, 'n presbiter van Alexandrië. Hy vra: "Hoe kan Jesus God wees op dieselfde manier as God die Vader?" Hy ontken nie Jesus se goddelikheid nie maar sê dit is heiligskennis om te dink dat Jesus van nature goddelik was - hy was 'n geskape wese. Arius se jong assistent Athanasius en sy biskop Alexander, het dadelik besef dat hier ingrypende vrae oor die aard van God gevra word en dat dit in wese vrae is oor die kwessie of Christus waarlik verlosser was. Hulle gaan Arius teë en dring aan op Jesus se ware goddelikheid in wese en essensie. Die kontroversie het so hewig geword dat Konstantyn self ingegryp en in 325 AJ 'n sinode by Nicea byeengeroep het om die leerstellings oor die persoon van Christus te finaliseer. In groot kosmiese redevoerings het die biskoppe gedebatteer en eindelik, ook onder druk van die keiser wat die vrede in sy ryk wou bewaar, is die Belydenis van Nicea wat Athanasius se standpunt ondersteun, deur die meerderheid onderteken. Die kerk het by Nicea 'n keuse gemaak vir die paradoksale inkarnasieleer ten spyte van die onversoenbaarheid daarvan met monoteïsme. Volgens Armstrong (1999:138) is die Drie-eenheid so'n onlogiese begrip dat dit nooit bedoel was om letterlik verstaan te word nie, maar dat dit Christene moes herinner dat die werklikheid wat hulle "God" noem, nie deur die menslike intellek begryp kan word nie.

Augustinus (354-430) se denke uit hierdie tyd het waarskynlik die blywendste invloed op beide die Katolieke Kerk en (deur hervormers soos Luther) die Protestantisme uitgeoefen. Vir hom was die elemente van die Drie-eenheid volkome gelykwaardig; van een substansie en tegelyk transendent en immanent. Die nalatenskap van sy antropologie het egter vir ons sekere probleme opgelewer. Daarvolgens is die mens tot verdoemenis veroordeel as gevolg van Adam se sonde wat vir ewig deur die vrou in die seksdaad voortgesit word. Augustinus se leer van die erfsonde het die mens van sy of haar liggaamlikheid vervreem en die vrou tot 'n minderwaardige wese verdoem wat tot vandag in die Christelike tradisie naklank vind. God is egter genadig en deur die goddelike uitverkiesing word sekere uitverkorenes gered. Die geskiedenis vertel van duisende sogenaamde ketters wat as gevolg van die leer van die erfsonde na die brandstapel gestuur is ( $\mathrm{vgl}$ Magee 2001:52; Noss 1980:450-454; Armstrong 1999:146).

\section{EENHEID: DIE GOD VAN ISLAM}

Rondom 610 AJ tree 'n nuwe godsdiens in die stad Mekka in Arabië na vore. Mekka het pas binne twee geslagte ontwikkel van 'n gewone nomadiese nedersetting tot die rykste en bloeiendste handelstad in Arabië. Mohammed 
ibn Abdallah, die stigter van Islam, was bekommerd omdat die ou bedoeïnestamwaardes van die inwoners besig was om deur harde kapitalistiese waardes vervang te word. 'n Gees van individualisme, kompetisie en hebsug het die plek ingeneem van die gemeenskapsetos van vroeër toe almal met mekaar gedeel en intens vir mekaar omgegee het.

Uit hierdie agtergrond het die een God van Islam ontwikkel. Die Arabiese stamme was vir eeue lank so heftig met mekaar in kompetisie vir oorlewing dat daar nie tyd was vir godsdiens in die konvensionele sin nie. Hulle het wel 'n hoë god, Allah ("die God"), geken en 'n panteon van mindere gode wat merendeels 'n noodlotsfunksie vervul het. 'n Ideologie van onverskrokkenheid in oorlogvoering, uithouvermoë in moeilike tye en toegewydheid aan die stam, was hulle godsdiens omdat dit oorlewing beteken het en godsdiens moes prakties wees. Die bestaan van God was dus nie vir Mohammed se hoorders 'n kwessie nie. Nou is hy egter as die enigste God verklaar. "Daar is geen God buiten Allah nie en Mohammed is sy boodskapper", lui die Moslemse credo. Die leer van èèn God het daarin geslaag om die gemeenskap weer te integreer en rondom hulle god saam te bind. Twee maal per dag (later vyf maal) moes laag in gebed voor Allah neergebuig word om hulle nietigheid en toegewydheid aan hom te betoon. Met hierdie verpligte gebedshouding wou Mohammed die egoïsme en arrogansie van sy mense breek. Daar was nie van Jode of Christene verwag om hulle tot Islam te bekeer nie, want alle godsdienste is gerespekteer. Verpligte dogmas oor Allah is nie ontwikkel nie, want dit sou net spekulasie wees oor dinge wat niemand kan weet of bewys nie. Hulle liefde vir die Koran word eksistensieel deur Moslems beleef as gevolg die poëtiese taal waarin dit geskryf is. Vir hulle is die taal van geloof nie rasionele taal nie maar die taal van poësie omdat net in simbole oor Allah gepraat kan word (Armstrong 1999:155-197).

Islam se verstommende sukses is 'n voorbeeld van hoe veranderende tye vernuwing in denke oor God meebring.

\section{DIE GOD VAN DIE FILOSOWE}

Niemand het daaraan gedink om die bestaan van God te probeer bewys voor die negende eeu nie en toe was dit Islam wat die groot denkers opgelewer het (Magee 2001:54). Hulle het in aanraking gekom met die Griekse wetenskap en filosofie en 'n goue eeu van wetenskapsopbloei beleef. Hulle steun op die rasionalisme van Aristoteles (384-322), wie se werke in die Arabiese wêreld behoue gebly het na die val van die Romeinse ryk in die vyfde eeu, en pas hulle analitiese benadering toe op die god van die Koran (Armstrong 2002:2122). Die failasufi's, soos die Moslemfilosowe bekend gestaan het, bly 
aanhangers van Allah, maar hulle beskou die rede en die filosofie as verhewe bo die godsdiens. Menslike eienskappe van Allah word gekritiseer en vir die eerste keer word letterlike verwysings na die hemel en hel figuurlik uitgelê. Leerstellings gebaseer op die Koran wat nooit voorheen bevraagteken is nie, soos die predestinasieleer, word aan die toets van die rede onderwerp. Die Koran was nie soos God 'n tydlose openbaringsgebeurtenis soos geglo is nie, maar deur mense geskep en eenmalig bekend gemaak om te voldoen aan die behoeftes van die tyd (vgl Noss 1980:521-522).

Intussen het die Grieks-Ortodokse kerk nie die behoefte aan rasionele vraagstelling ontwikkel nie. Hulle het die perke van hulle eie metafisika geken. Hulle het geweet dat logika en die rede goed was vir dissiplines soos medisyne en wiskunde maar nie vir God nie - so min as wat die effek van 'n musiekstuk met die rede verklaar kan word.

Teen die tiende en elfde eeue is die failasufi's deur konserwatiewe groepe gedwing om hulle wetenskaplike toetsing van God te laat vaar omdat dit God omskep het in 'n veraf onbetrokke wese wat vir die geloof van die gewone mense min beteken het. Hulle het hulle tot die sufisme (mistiek) gewend en in die twaalfde eeu was ibn al-Arabi se gevolgtrekking dat God slegs in die diepste van elke mens se wese bestaan. Elkeen ervaar dus sy of haar god verskillend en elke ontmoeting met die naaste is 'n godservaring want God is teenwoordig onder die oppervlakte van elkeen van sy skepsels (Armstrong 2002:22).

Die gedagtes oor God as 'n subjektiewe ervaring het die era van die mistiek ingelui.

\section{DIE GOD VAN DIE MISTICI}

Teïsme, of die idee van 'n persoonlike, betrokke god is deur al drie monoteïstiese godsdienste ontwikkel. 'n Persoonlike god is antropomorfies, wat beteken dat hy menslike eienskappe het: "hy" is van die manlike geslag, kan liefhê, oordeel, straf, hoor, skep en vernietig netsoos die mens. Veral in die Christendom was 'n persoonlike god, verteenwoordig deur Jesus wat mens geword het, sentraal (Geller 1997:319). Die gevaar is egter dat menslike behoeftes, vrese en vooroordele op so'n god geprojekteer word en dat menslike dade as die "wil van God" geregverdig word. In die geskiedenis het dit meegebring dat menige gruwels in sy naam gepleeg is. Al drie godsdienste het die probleme van so'n god besef en 'n mistieke tradisie ontwikkel waarin God 'n numineuse entiteit is soos nirvana in die Boeddhisme. Die strewe van die mistici is om die self af te lê en deur meditasie, vas en ander tegnieke, èèn te word met die diepste grond van die werklikheid. 'n Mistieke ervaring van God is 'n ekstatiese, subjektiewe 
ervaring van die kreatiewe verbeelding. Dit behels 'n "reis na binne" wat nie met serebrale denke bereik kan word nie (Krüger 1995:274-290; Armstrong 1999:246). In die Weste was die Christene traer as die sufi's van Islam en die kabbaliste van die Judaïsme om 'n mistieke spiritualiteit te ontwikkel, maar tragedies soos oorlog en die Swart Dood wat Europa geteister het, sowel as 'n onderlinge ontevredenheid met die Katolieke Kerk, het in die laatMiddeleeue gelei tot 'n ontploffing van Christelike mistiek in die Weste. Die leidende motief in die kuns is die passie van Christus en bebloede, verwronge kruisigingstonele word uitgebeeld. In haar verlange om in Christus se lyding te deel, beoefen Julian van Norwich (1343-1413) diep meditasie waarin sy deur visioene van die kruisiging, Christus se pyn persoonlik ervaar en oorspoel word deur 'n gevoel van vrede en verlossing wat van die Christusfiguur vloei (Gaul 2004:142). Meister Eckart (1260-1327) reageer teen die uiterlike vertoon en bombasme van die kerk en verkies om die via negativa te volg en God as Niks of Nie-Wese aan te spreek omdat God so onbegryplik is dat slegs in negatiewe terme na hom verwys kan word (Haught 1990:117).

Uiteindelik het hierdie onbybelse spiritualiteit teenstand gekry van die hervormers van die sestiende eeu. Die gevolg was dat Europa God in nog meer rasionele terme sou begin sien.

\section{9. 'N GOD VIR DIE HERVORMERS}

Die vyftiende en sestiende eeue word gekenmerk deur 'n behoefte aan godsdienstige hervorming en dit sou beslissend wees vir alle mense van God. Die Hervorming het egter 'n gees van vrees in Europa meegebring. 'n Oorheersende obsessie met sonde, die hel en satan het mense nie gelukkig gemaak nie en tussen God en die mens het 'n oneindige afstand ontstaan. Kritiese vrae oor God was nie 'n oorweging nie, want godsdiens en die kerk het elkeen se persoonlike lewe sowel as universiteite, gildes en die kunste oorheers. Dit was egter ook die tyd van die Renaissance en die humanisme wat die mens as middelpunt opgestel het en ontdekkingsreise wat nuwe vastelande sou oopmaak. 'n Oorgangstyd dus, waarin groot figure na vore sou tree om kerklike vernuwing te bring. In die proses word Europa in twee strydlustige kampe verdeel: Katoliek en Protestant (Noss 1980:470,471; Armstrong 1999:296, 317, 330).

Dit was ook 'n krisistyd vir Moslems en Jode. Na die lang Mongoolse besetting ontstaan 'n nuwe konserwatisme in Islam om te red wat nog te red is en hulle keer terug na die oorspronge, na die Koran en die heilige Shariawette. Dit bring 'n gees van onverdraagsaamheid mee wat Islam nie voorheen geken het nie. Die Jode bevind hulle weer in ballingskap as hulle in die vyftiende eeu oral uit Europa verdryf word in 'n vlaag van anti-semitisme. 
Baie keer terug na Palestina - na Safed in Galilea - waar 'n nuwe kabbala ontstaan om God opnuut te vind (Armstrong 1999:297-311).

In Duitsland lei Martin Luther (1483-1546) die hervormingsbeweging in. Luther se god was in die begin van sy lewe 'n god van woede en vergelding. Luther het gebuk gegaan onder 'n diep sondebesef en 'n onmag om God tevrede te stel, ten spyte van die sakramente en foltering van sy liggaam. Hy vind sielerus in Paulus se uitspraak in Romeine 1:17 dat die regverdige uit die geloof sal lewe. Daarvolgens word die mens van sonde vrygemaak, nie deur goeie werke, die nakoming van die Wet of die kerk se afkoopboetes nie, maar deur te glo dat God in sy liefde en genade redding vir elkeen moontlik maak. Dié God maak homself bekend in die waarhede van die heilige Skrif (Armstrong 1999:317-321; De Klerk 1977:107).

Johannes Calvyn (1505-1564) het 'n meer ingrypende en blywende invloed op die Westerse Christendom gehad. Soos Luther het hy die almag van God en die gesag van die Bybel sentraal gestel. Hy word onthou vir sy geloof in die predestinasie- en uitverkiesingsleer. God is in beheer van alles wat op aarde en in die geskiedenis gebeur en sy wil is onpeilbaar maar ewig en regverdig. Die mens is deur die erfsonde besoedel en staan skuldig voor God. Maar nie almal is verlore nie want van die voortyd af het God besluit wie gered sou word en wie vir die ewige verdoemenis beskore is (De Klerk 1977:117). Hierdie leer was natuurlik vir die humaniste wat die mens se vrye wil voorgestaan het, onaanvaarbaar.

Calvyn se lyn van denke het hom met somber erns na die lewe laat kyk. Ligsinnigheid en wêreldse plesier was uit die bose (dans is deur die wet verbied en egbreuk met die dood gestraf), terwyl selfdissipline, pligsgetrouheid en spaarsaamheid as goddelike deugde beskou is (Noss 1980:474). Die Calvinistiese god het mense tot angs en vrees, depressie en selfs selfmoord gedryf, maar hulle het ook ' $n$ harde onverdraagsaamheid ontwikkel teenoor diegene wat volgens hulle nie uitverkies is nie. In baie gevalle het dit tot bloedvergieting gelei, wat die gevaar van 'n "menslike" godsbeeld uitwys. Om 'n god in te dink wat letterlik verantwoordelik is vir alles wat op aarde gebeur, hou onmoontlike teenstrydighede in. Dan word God soos 'n gevoellose despoot wat die wêreld regeer in plaas van 'n simbool van dit wat mense moed gee om tragedie en spanning te oorleef ( $\mathrm{vgl}$ Armstrong 1999:326, 329). Die onhoudbaarheid van die uitverkiesingsleer en die god wat daarvoor verantwoordelik sou wees, moet toegeskryf word aan die hervormers se letterlike verstaan van die Bybel en die "sondeval" van Genesis 3.

Die letterlike verstaan van die Bybel is sentraal gestel deur beide die Katolieke en Protestante nadat Copernicus (1530) en Galileo (1613) se 


\section{Jaar van soeke na God}

heliosentriese teorie in hierdie tyd veroordeel is op die aanklag dat dit God se woord in die Bybel weerspreek. Terwyl die mistici, kabbaliste en sufi's die Bybel en die Koran simbolies uitgelê het, was God vir die nuwe literalistiese Christene 'n objektiewe feit.

Van die begin van die sewentiende eeu tot vandag word die bestaan van God op rasionele gronde bespreek. Wetenskap sou geloof vervang en dit was ammunisie vir toekomstige ateïste om die god te verwerp wat mense met vrees in plaas van hoop en vertroue vul.

\section{VERLIGTING}

Die agtiende eeuse Verligting in Europa was die draaipunt van die Middeleeuse supernaturalistiese-mitiese-outoritêre denke na die "moderne" tyd se naturalistiese-wetenskaplike-individualistiese denke (Baumer 1977:141).

Die aanloop daarvan is die proses van tegnologisering wat met die uitgang van die sestiende eeu in die Weste begin het. Dit het 'n nuwe soort samelewing voortgebring wat aan God 'n nuwe rol toegeken het. In die plek van 'n landboukultuur wat van die natuur se kwesbare hulpbronne afhanklik is, bring die tegnologie industrialisasie mee met ingeboude ekonomiese bronne wat onafhanklikheid van goddelike ingrype meegebring het. Die era van modernisme het aangebreek. Die mens se nuut-ontdekte mag oor die natuur en die wetenskaplike prestasies van hierdie tyd lei tot optimisme en selfvertroue wat gevestigde gesagsinstansies soos die kerk, bybelse gesag en die Christelike tradisie uitdaag (vgl Magee 2001:69-70). Die nuwe Weste word geïnspireer deur nuwe mites: verandering, vooruitgang, spesialisasie en die rasionele vermoë van die individu (Armstrong 1999:337-341).

In die wetenskaplike gees van die tyd is daar nie ruimte vir 'n persoonlike God of vir verbeelding, mistiek, mites en openbaring nie. Sekerheid oor God kan net deur die intellek voorsien word. Die rasionalistiese denkers van die sewentiende eeu het nie aan die bestaan van God getwyfel nie, hulle wou dit juis bewys, maar dit moes op rasionele gronde gedoen word (Baumer 1977:70, 188).

Newton (1642-1727) se godsbeskouing is nie op die Bybel gebaseer nie. Hy beskou die Drie-eenheid en inkarnasie as primitiewe fantasieë van die bygelowige massas. As fisikus reduseer hy God tot 'n rolspeler in sy eie meganiese sisteem. Volgens hom kan God bewys word deur die werking van die heelal waar te neem want die beweging van die planetêre hemelliggame moes 'n Eerste Oorsaak hê, 'n Groot Ontwerper wat die prosesse van die heelal bestuur en instand hou (Baumer 1977:72-78). Descarte (1596-1650) as wiskundige, glo dat die mens die waarheid kan ontdek deur die rede en die 
regte metode. Hy redeneer vanuit die denkende self as bron van sekerheid. Die bestaan van God is vas en seker, want die idee van God as volmaakte Opperwese is inherent in elke mens se bewussyn vasgelê en die een ding waarvan die mens seker kan wees, is dat hy of sy 'n denkende wese is: cogito, ergo sum. Pascal (1623-1662) was 'n praktiserende Katoliek en nie so positief oor die vermoë van die rede om God te bewys nie. Hy is die eerste persoon om te beweer dat geloof in God 'n kwessie van persoonlike keuse is. Dit is 'n dobbelspel, 'n sprong in die duister, maar 'n keuse vir God is positief omdat dit sin en betekenis gee aan die gelowige se bestaan. Pascal se "verborge" God is nuut in die geskiedenis van monoteïsme omdat God se bestaan nog nie voorheen bevraagteken is nie (Baumer 1977:72; Armstrong 1999:343).

In die agtiende eeu beweeg die denke na empirisme. Dit wil sê, gevolgtrekkings moet op sintuiglike ervaring en eksperimentering, eerder as op die rede, gebaseer wees. God moes, soos alle objekte daarbuite, geverifieer kan word. Deïsme, die nuwe godsbeskouing, stel God voor as 'n onpersoonlike, afwesige god wat hom nie met gebeure op aarde bemoei nie. Kortom, in Kant se woorde: "Die deïs glo in 'n God, die teïs glo in 'n lewende God" (vgl Baumer 1977:193). In 1764 beskryf Voltaire die nuwe godsdiens as een wat meer gemoeid is met moraliteit as dogma; wat nie van die mens verwag om in onmoontlike, weersprekende leerstellings te glo nie; wat nie die mens dreig met ewige straf nie, maar wat in 'n God glo wat regverdig, verdraagsaam en medemenslik is (Armstrong (1999:356). Armstrong merk op dat die kerke hulleself te blameer het vir dié reaksie omdat gelowiges deur die eeue oorweldig is deur te veel verlammende leerstellings wat nie vir die gesonde verstand sin maak nie. ${ }^{4}$

Deur God te bespreek asof hy 'n objektiewe feit is, is die weg gebaan om heeltemal van God ontslae te raak. Holbach (1723-1789) verklaar God as oorbodig omdat die natuur, insluitend die mens, net 'n enorme proses van oorsaak en gevolg is. Laplace (1749-1827) verban God uit die fisika want planeet Aarde is niks meer nie as 'n weerspieëling van die son se lig en hitte.

Vir eeue lank het gelowiges in elk van die monoteïstiese godsdienste aangedring dat God nie maar bestaan soos ander fenomene nie. In die Weste egter, het Christenteoloë die nuwe wetenskap aangegryp om die objektiewe werklikheid van God te bewys deur God soos enige objek te toets en te analiseer. Holbach en Laplace keer hierdie poging om en kom tot dieselfde gevolgtrekking as die ekstreme mistici: daar is niks buiten die voorhandene

\footnotetext{
${ }^{4}$ In Beeld 13 Oktober 2004 verskyn 'n brief van 'n lidmaat met die opskrif: Kerke sal leegloop solank die verstand nie bevredig word nie.
} 


\section{Jaar van soeke na God}

nie. Nou was die tyd in Europa ryp om God dood te verklaar (vgl Baumer 1977:197).

In Engeland en die Nuwe Wêreld egter, was God 'n lewende werklikheid vir die aanhangers van die Metodisme, 'n nuwe beweging wat onder leiding van John Wesley (1703-1791) in reaksie teen die koue verstandsgodsdiens van die Verligting ontstaan het. Wesley wou die veraf god van die deïste terugbring na die nuut-verstedelikte mense wat ankerloos in armoede geleef het. Opswepende preke bring 'n golf van bekerings mee wat met ekstatiese en irrasionele emosies gepaard gaan. Die nuwe kerk versprei na die Amerikaanse kolonies waar Jonathan Edwards (1703-1758) se prediking lei tot die "Great Awakening" van 1730, 'n hernuwingsbeweging wat die onderdrukte laer klasse hoop gee en kenmerkend van 'n fundamentalistiese Bybelbeskouing, tot opstande en rewolusie inspireer in afwagting op die nabye koms van God se koninkryk (vgl Noss 1980:497-488).

\section{DIE EKLIPS VAN GOD}

Deur die negentiende eeu was ateïsme in Europa op die agenda, maar in die twintigste eeu was dit 'n voldonge feit. Die idee van God wat vir eeue lank in die Christelike Weste bestaan het, was uitgedien. In sommige gevalle is dit verstaanbaar. Veral die persoonlike, antropomorfiese God was kwesbaar omdat diè god in die geskiedenis met rampspoedige gevolge misbruik is. Verder het godsdiens eenvoudig nie meer in die heersende wetenskaplike wêreldbeeld gepas nie.

Die kunstenaars en digters uit die Romantiek sou nog die natuur in hulle werke voorstel as die plek waar God gevind kan word (Baumer 1977:278), maar oorwegend was dit die eeu waarin denkers soos Feuerbach, Marx, Darwin, Nietzshe en Freud die werklikheid voorgestel het sonder ruimte vir God. Volgens Feuerbach (1804-1872) is God 'n projeksie van die mens se onvervulde verlangens. God word boonop so heilig en verhewe teenoor die nietige, sondige mens voorgestel dat die mens alle selfwaarde verloor het. Die mensdom kan klaarkom sonder 'n god wat mense van hulleself vervreem. Marx (1818-1885) sien religie as opium om die massas se lyding draaglik te maak. Charles Darwin se evolusieteorie (1859) maak God om verstaanbare redes oorbodig. Nietzshe (1844-1900) verklaar God dood, waarmee hy bedoel dat die mensdom nie meer in God kan glo nie. Die Christelike God het onder andere deur 'n sieklike moraliteit by mense 'n vrees ingeboesem vir hulle liggaamlikheid en seksualiteit. Elke mens is verplig om dié moraliteit drasties te hersien en elke dag hier en nou voluit te lewe. Freud (1856-1939) se god is 'n projeksie van mense se behoefte aan onder meer 'n vaderfiguur en die ewige lewe (Armstrong 1999:406-410). 
Ten slotte egter, het God in die twintigste eeu vir baie Jode in die vlamme van Auschwitz se krematoriums opgegaan. Die twee vernietigende wêreldoorloë het beslissend bygedra tot die sekulêre Europese kultuur van die twintigste eeu.

Eksistensialistiese filosowe soos Heidegger (1889-1976), Sartre (19051980) en Camus (1913-1960) spreek die dilemma van die twintigste eeuse mens aan wat oortuig is van God se dood, maar ' $n$ wanhopige bestaan voer sonder transendente betekenis, en tog bewus van 'n diep behoefte daaraan. Die nuwe mentaliteit is een van absurditeit, vervreemding en 'n gevoel van verlies, verlies aan geloof in 'n bo-aardse teenwoordigheid te midde van 'n onseker toekoms en die naderende dood (Baumer 1977:441; 414). Heidegger en Sartre beklemtoon die intellektuele vryheid van die individu om in 'n godlose wêreld self keuses te maak en self 'n lewe te skep, wel wetende dat onsekerheid oor die uitkoms daarvan ook angs meebring. Camus, bekend as die "heilige sonder 'n God", rig 'n uitdaging om God te verwerp en deernis en empatie op die mensdom uit te stort, want passievolle ateïsme kan meer religieus wees as 'n "moeë" teïsme (vgl Magee 2001:208-217; Armstrong 1999:433).

Paradoksaal, was die twintigste eeu ook 'n tyd waarin teoloë ernstig oor God besin het. Die neo-Ortodoksie wou antwoorde vind op die historisme en historiese kritiek van die Verligtingsdenke wat die ewige waarhede van die geloof en die Bybel gerelativeer het. Ook die immanente God van die liberalisme wat deur menslike ervaring kenbaar is, het ' $n$ nuwe teologie vereis (vgl Baumer 1977:442-444). Barth (1886-1986) stel 'n god bekend wat so verhewe is dat 'n onoorbrugbare kloof hom van die mens en die wêreld skei. Diè god kan nie met die rede of deur ervaring geken word nie, maar word slegs deur die Bybel aan die mens geopenbaar. Tillich (1886-1965) is deels 'n eksistensialis en verwerp die persoonlike God van die teïsme wat die mens se vryheid inperk. Ons moet 'n God "bo" die objektiewe persoonlike God vind, wat net in simboliese taal beskryf kan word en in menslike ervaring geken kan word (Baumer 1977:443-449; Armstrong 1999:437-439). Bonhoeffer (19061945), wat op 'n jong ouderdom in die Nazi-gevangenis van Flossenburg sy lewe verloor het, het gesien dat Europa 'n keerpunt bereik het en 'n nuwe religieuse bestel binnegaan. Hy noem dit 'n "godsdienslose Christendom". Die mens het mondig geword en afskeid geneem van die gesag van God, die Christendom en die kerk wat 'n onegte lewe afgedwing het. Die einde van die religieuse Christendom, sê Bonnhoefer, kan egter die begin wees van 'n egte, outentieke christelike geloof (vgl Weiland 1972:86-99).

Die Logiese Positiwiste van die vyftigerjare vind die idee van God sinloos omdat net uitdrukkings wat empiries bewys kan word, empiriese betekenis het en metafisiese taal kan nie empiries getoets word nie. Ateïsme sowel as teïsme is dus betekenislose begrippe. Maar terwyl wetenskaplike 
bewyse goed werk vir objektiewe feite, is geloofstaal inderdaad onbewysbaar en nie geskik vir hierdie soort argument nie (Magee 2001:199; vgl Armstrong 1999:434).

Volgens die Prosesteologie, waarvoor die Britse filosoof, Whitehead (1861-1947) onthou word, is God in die wêreld en deel van die wêreld se prosesse. Hy is steeds en voortdurend besig om in en om ons te skep. God deel die mensdom se lyding, hy is die "great companion, the fellow-sufferer, who understands" (Baumer 1977:453; Armstrong 1999:440). Verstaanbaar, het hierdie teologie baie beteken vir 'n oorlog-geteisterde Europa en is dit steeds 'n antwoord op die mensdom se waarom-vrae

Sedert die sewentiger jare van die vorige eeu steek 'n gevaarlike soort fundamentalisme in al drie God-religieë kop uit. Diè hoogs politiese spiritualiteit het 'n letterlike, moralistiese en onverdraagsame uitgangspunt wat God gebruik om andersdenkendes se bestaanreg te ontken. In die Christelike vorm daarvan kom min tereg van Christus se medelye en deernis. Dit ken ons uit die Suid-Afrikaanse politieke verlede. In Amerika skaar die Christelike fundamentaliste hulle dan ook by die regse politieke partye. Islamitiese fundamentalisme het regerings laat tuimel en op 11 September 2001 ook die Twee Torings (in New York) van Manhattan. Judaïstiese fundamentaliste verdryf die Arabiere met geweld uit hulle toegewysde gebiede in Israel om hulle godsdienstige obsessie vir 'n Joodse staat te verwesenlik. Dit blyk dat die fundamentalistiese god van die Jode, Christene en Moslems 'n ongelukkige oorsprong gehad het in die vroeë stammegod van Israel wat partydig was vir sy eie volk tot die uitwissing van ander volke (vgl Armstrong 1999:447-449).

Met die twintigste eeuse Europese godsbeskouing word die verhaal van God afgesluit. Deur die verskillende godsbeelde te verstaan teen die agtergrond van die tyd en omstandighede waarin dit ontstaan het en dit te herbedink saam met die denkers van die afgelope vier millennia, is ons hopelik wyser en by magte om die implikasies daarvan op te weeg.

\section{BESINNING OOR DIE TOEKOMS VAN GOD}

Die artikel eindig waar dit begin het, met die kwessie van kritiese vraagstelling oor die tradisionele God wat rondom ons opgaan. Dit kan nie geïgnoreer word nie want Christene soek leiding en het 'n behoefte om te praat oor hulle vermoedens en twyfelvrae. ${ }^{5}$ Daarvan kan predikante en die Nuwe Hervorming Netwerk (NHN) wat aan die behoefte probeer voldoen, getuig. Gesonde

\footnotetext{
${ }^{5}$ Die onlangse tsoenami's wat duisende lewens in Oos-Asië geëis het, het opnuut artikels en briewe oor God se aandeel aan die ramp aldan nie, in die dagblad Beeld uitgelok. Kyk Beeld (2005:13); Beeld (2005:12). Opskrifte in die briewekolomme reflekteer die publiek se reaksie (Beeld 2005:14).
} 
ikonoklasme, het ons gesê, is deel van die natuurlike dinamiese prosesse van geloofsisteme. Die algehele sekularistiese gees wat in Europa heers, is egter nuut in die menslike geskiedenis en die langdurige uitwerking daarvan is onbekend. Dit is normaalweg nie in die menslike aard om met leegheid en verlatenheid saam te leef nie. Nuwe simbole om betekenis aan mense se lewens te gee, is nog altyd in die verlede gevind en sal weer gevind word om die vakuum wat deur die verduistering van God veroorsaak is, te vul. Wat kan ons leer uit die herhalende temas in die verhaal van God as ons wil hê dat die idee van God moet voortleef?

- Die fundamentalistiese godsbeeld is onaanvaarbaar en nie goeie teologie nie. Dit is in wese 'n opskorting van die sentrale monoteïstiese ideaal waarmee die profete van ouds die vroeë Jahwekultus hervorm het, naamlik medemenslikheid in plaas van offerande en genade in plaas van skynheilige geregtigheid. Toegewyde Christene van vandag veroordeel ander, hetsy van geloof, ras of seksuele oriëntasie op grond van 'n letterlike Bybelgebruik sonder begrip vir die menslike outeurskap van die Bybel en die gaping wat tussen die premodernistiese geskrifte en vandag se postmodernistiese denkwêreld bestaan (vgl Vorster 1994:19-68).

- Die verhewe Opperwese van die agtiende eeuse deïste is so ver verwyder en onbetrokke by mense se daaglikse bestaan dat hy soos 'n deus otiosus, ' $n$ irrelevante god, vervaag in die mensdom se bewussyn (Armstrong 1999:454). Om, soos Newton, God se bestaan wetenskaplik te "bewys", word nie meer aanvaar nie want God en godsdiens is van 'n ander orde as die natuurwetenskappe. Dit het die wetenskaplikes ons ook geleer. Op 'n vraag oor watter implikasies sy relatiwiteitsleer vir die teologie inhou, was Einstein se antwoord: "None. Relativity is a purely scientific matter and has nothing to do with religion" (vgl Armstrong 1999:453). Einstein het ook beweer dat God en die wetenskap mekaar nie uitsluit nie, maar aanvul. Wetenskaplike teorieë en modelle is nie feite of absolute waarheid nie, maar voorlopige, menslike konstrukte wat met die ontwikkeling van kennis, telkens vervang word deur teorieë en modelle wat die werklikheid beter beskryf. Die doel van die wetenskap is om kwantitatiewe resultate te lewer, terwyl geloofsuitdrukkings, verhale, poësie en musiek die kwalitatiewe sy van die lewe in die prentjie bring deur uitdrukking te gee aan die ervarings van nietige mense in hulle strewe om sin en orde te skep in 'n chaotiese wêreld ( $\mathrm{vgl}$ Van Wolde 1996:259-262). 


\section{Jaar van soeke na God}

- Onderliggend aan die godsbeelde wat hierbo bespreek is, is 'n persoonlike, antropomorfiese god. Dit geld Newton se god wat die heelal geïnisieer het en die partydige, moralistiese god van die fundamentalisme, sowel as die menslike god wat deur die agtiende eeuse ateïste verwerp is op grond van sy outoritêre optrede. Hierdie god is volgens Bowker (2003:310) 'n objek buite onsself wat soos 'n pakdier gelaai word om ons eie voorkeure en vooroordele saam te dra. Soos ' $n$ refrein het ons gehoor dat 'n god wat optree soos 'n groter weergawe van onsself, bevraagteken word omdat onnoembare dade in sy naam gepleeg word. Selfs natuurrampe en siektes word aan sy wil toegeskryf. Of soos die straffende, veroordelende God van die Hervormers, belaai hy "sondige" mense met ondraaglike skuldgevoelens. Feministe vind dit moeilik om te identifiseer met die manlike geslag van die persoonlike God omdat dit deur die eeue die ondergeskikte posisie van vroue instand gehou het (Klopper 2002:421438). Mary Daly (1973:19) se bekende frase: "If God is male, then the male is God", vertolk die essensie van die probleem.

- Die God van die mistiek is 'n alternatief. Hy of sy of dit is nie 'n objektiewe feit wat wetenskaplik bewys kan word of menslike eienskappe het nie, maar'n subjektiewe ervaring wat deur die verbeelding ervaar word. Hierdie werklikheid simboliseer die onuitspreeklike misterie van die lewe. Met ons Westerse serebrale, empiriese mentaliteit is dit egter nie maklik begrypbaar nie. Dit neem tyd en opleiding om deur meditasie 'n gewaarwording daarvoor te ontwikkel en ons leef nou eenmaal in 'n kitskultuur wat God in klaar-verpakte definisies verkies. Armstrong (1999:454-455) stel voor dat ons ten minste van die mistici kan leer om nie onbedag die dogmatiese verpakkings as die waarheid oor die werklikheid wat ons "God" noem, te aanvaar nie.

Maar miskien is God nie dood nie. Miskien soek ons God op die verkeerde plekke (Müller 2004a:14; Armstrong 2002:29-30). Miskien is God of goddelikheid of lewenssin - die benaming is onbelangrik - daar te vind waar ons die tragedie en ekstase van die lewe ten diepste ervaar: in die goedheid en nood van die naaste; in die skoonheid en felheid van die natuur; in aangrypende musiek en woorde, of in die intieme eenword met iemand wat ons liefhet. Miskien is God die lewe - onvolledig en immer veranderend maar onteenseglik teenwoordig. Miskien moet ons die God van die lewe ons eie maak en ons eie God van die lewe maak. 


\section{Literatuurverwysings}

Armstrong, K 1999. A History of God: From Abraham to the present. The 4000-year quest for God. London: Vintage.

Armstrong, K 2002. The God of imaginitive compassion, in Schmidt, F W (ed), The changing face of God, 15-32. Harrisburg, PA: Morehouse.

Baly, D 1970. The geography of monotheism, in Frank, H T \& Reed, W L (eds), Translating \& understanding the Old Testament: Essays in honour of Herbert Gordon May, 253-278. Nashville, TN: Abington.

Baumer, F L 1977. Modern European thought: Continuity and change in ideas, 16001950. New York: Macmillan.

Bowker, J 2003. God: A brief history. London: Dorling Kindersley.

Daly, M 1973. Beyond God the Father: Toward a philosophy of women's liberation. Boston, MA: Beacon.

De Klerk, P 1977. Die opkoms van Europa 1500-1815. Durban: Butterworths.

Eliade, M 1959. The sacred and the profane. The nature of religion. San Diego, CA: Harcourt Brace Jovanovitch.

Frymer-Kensky, T S 1992. In the wake of the goddesses: Women, culture, and the Biblical transformation of pagan myth. New York: Free Press.

Gaul, L 2004. "Performativity" in the lives of Julian of Norwich (1343-1413) and Margery Kempe (1373-1438). DLitt et Phil thesis, Rand Afrikaans University.

Geller, S A 2000. The God of the covenant, in Porter, V N (ed), One God or many? 273-319. Casco Bay Assyriological Institute: Conference proceedings.

Gibson, J C L 1978. Canaanite myths and legends. Edinburgh: T \& T Clark.

Gnuse, R K 1997. No other gods: Emergent monotheism in Israel. Sheffield: Sheffield Academic Press. (JSOTSS 241.)

Haught, J F 1990. What is religion? An introduction. New York: Paulist Press.

Jacobs, M M 2004. Goddelikheid en die historiese Jesus: Die ont-dogmatisering van Jesus en die misterie van God. Referaat gelewer tydens die C B Powellseminaar: Om vandag oor goddelikheid te praat. 'n Groot misterie? UNISA.

Klopper, F 2002. Women, monotheism and the gender of God. In die Skriflig 36(3), 421-438.

Krüger, J S 1995. Along Edges. Religion in South Africa: Bushman, Christian, Buddhist. Pretoria: UNISA.

Landman, C 2005. God kan tsoenami's stuur of afweer: Hy is soewerein. Beeld 13 Jan 2005, bl 14.

Magee, B 2001. The story of philosophy. London: Dorling Kindersley.

Müller, J 2004a. Leer God raaksien in onwaarskynlike. Beeld 17 Mei 2004, bl 4.

Müller, J 2004b. God omstrede in wêreld wat groei. Beeld 4 Okt 2004, bl 12.

Noss, J B 1980. Man's Religions. $6^{\text {th }}$ ed. New York: Macmillan.

Potgieter, F 2004. Kerke sal leegloop solank verstand nie bevredig word. Beeld 13 Okt 2004, bl 12.

Spangenberg, I J J 2004. Om oor God te praat: 'n Kritiese oorsig van gesprekke onder Afrikaanssprekende Christene van die gereformeerde tradisie (19982003). Verbum et Ecclesia 25(1), 274-293.

Spangenberg, I J J 2005. Tsoenami's geen “daad van God”. Beeld 10 Jan 2005, bl 12. 
Van den Heever, G \& Scheffler, E (eds) 2001. From Jesus Christ to Christianity: Early Christian literature in context. Pretoria: UNISA Press.

Van der Merwe, J 2005. Onkunde en bygeloof: Nie God wat ramp bring. Beeld 12 Jan 2005, bl 13.

Van Wolde, E 1996. Stories of the beginning: Genesis 1-11 and other creation stories. London: SCM.

Vorster, J N 1994. Fundamentalism. Tutorial Letter 102/1994 for BSA302-3.

Weiland, J S 1972. Oriëntatie: Nieuwe wegen in de theologie. 6e druk. Baarn: Wereldvenster. 